\title{
PENGARUH TATA RUANG TERHADAP PERILAKU WISATAWAN DI KAWASAN NOL KILOMETER YOGYAKARTA
}

\section{Aisha Astriecia}

Universitas Teknologi Yogyakarta

e-mail: aisha.astriecia@gmail.com

\begin{abstract}
ABSTRAK
Kawasan Titik Nol Kilometer merupakan salah satu destinasi wisata yang menjadi satu rangkaian dengan kawasan wisata Malioboro. Kawasan Titik Nol Kilometer selain menjadi destinasi wisata, juga merupakan kawasan cagar budaya dan ruang publik yang memiliki keunikan pada fungsi keruangannya dan bangunan-bangunan tua di sekitarnya. Hal tersebut menjadikan kawasan ini sering dimanfaatkan pengunjung sebagai tempat untuk berkumpul maupun tempat singgah menikmati suasana Kota Jogja. Penataan kawasan Titik Nol Kilometer dilihat secara visual memiliki perbedaan di setiap sisinya yang mempengaruhi pola perilaku wisatawan, terutama saat malam hari. Penelitian ini dilakukan untuk mengidentifikasi pengaruh tata ruang di pelataran kawasan Titik Nol Kilometer Yogyakarta terhadap perilaku pengunjung di tiap sisi pelataran. Metode penelitian yang digunakan adalah deskriptifobservatif. Berdasarkan hasil penelitian, pelataran sisi Barat atau zona penelitian satu cenderung jarang disinggahi pengunjung dikarenakan penataan ruang yang lebih padat, pencahayaan yang redup, dan aroma yang tak sedap, sehingga wisatawan merasa kurang nyaman berada di zona tersebut. Sedangkan di sisi Timur cenderung lebih ramai dikarenakan lebih terbuka, sehingga pengunjung dapat melihat secara menyeluruh bangunan budaya yang terdapat di kawasan ini.
\end{abstract}

KATA KUNCI: titik nol; perilaku; tata ruang; destinasi wisata

\section{PENDAHULUAN}

Kawasan Nol Kilometer atau Titik Nol Kilometer merupakan salah satu ikon wisata di Kota Yogyakarta yang masih merupakan bagian dari kawasan wisata Malioboro. Titik Nol Kilometer memiliki keunikan sebagai destinasi wisata, yakni terdapatnya bangunan cagar budaya yang masih difungsikan sebagai perkantoran di sekelilingnya. Keberadaan bangunan cagar budaya merupakan atraksi utama di destinasi ini yang secara visual dapat dilihat dan dinikmati dari pelataran Titik NolKilometer. Keunikan lain destinasi ini adalah fungsi kawasannya yang selain sebagai destinasi wisata juga merupakan ruang publik ditandai dengan seringnya dimanfaatkan sebagai titik kumpul maupun tempat berkumpul komunitas.

Daya tarik utama wisata Titik Nol Kilomater adalah bangunan bersejarah di sekitarnya yang menuntut penataan kawasan ini mendukung kebutuhan wisatawan untuk singgah dan menikmati suasana Kota Yogyakarta dengan bangunan bersejarahnya. Bentuk penataan ruang di destinasi ini adalah ruang terbuka, namun penataan ruang pada pelataran sisi Barat (yang selanjutnya disebut zona satu) dan sisi Timur (yang selanjutnya disebut zona dua) memiliki desain yang berbeda.

Titik Nol Kilometer terletak di simpang empat Jalan Panembahan Senopati, KH. Dahlan, Pangurakan, dan Margo Mulyo. Titik yang dimanfaatkan pengunjung dalam menikmati suasana Kota Jogja terletak pada pelataran Barat dan Timur atau bagian Utara jalan K.H Dahlan dan Panembahan Senopati. Pelataran sebagai sarana penunjang bagi pengunjung untuk singgah menuntut disediakannya fasilitas seperti kursi taman, papan penunjuk, tempat sampah, lampu, dan pembatas jalan. Namun, persebaran fasilitas penunjang di zona satu dan dua memiliki perbedaan apabila dilihat dari penataan perabot atau fasilitasnya. Fasilitas yang terdapat di zona dua lebih minim dibandingkan zona satu, namun memiliki pencahayaan yang lebih terang. Penelitian ini akan melihat pengaruh penataan ruang yang berbeda pada pelataran sisi Barat dan Timur di Titik Nol Kilometer terhadap perilaku wisatawan saat singgah di destinasi ini. 


\section{TINJAUAN PUSTAKA}

\section{Destinasi Wisata Budaya}

Destinasi wisata budaya menjadikan budaya sebagai komponen wisata yang utama, sehingga merupakan motivasi utama bagi wisatawan untuk berkunjung. Wisata budaya dapat pula dikategorikan sebagai wisata minat khusus karena pengunjung yang datang memiliki ketertarikan tertentu (Swarbrooke dan Horner, 2007). Daya tarik yang termasuk dalam wisata budaya meliputi bangunan bersejarah, situs, monumen, pertunjukan seni, peninggalan keagamaan, kegiatan atau cara hidup masyarakat, patung kontemporer, dan kuliner lokal (Pitana dan Diarta, 2009).

\section{Wisatawan}

Wisatawan dapat diartikan sebagai seseorang yang melakukan perjalanan untuk berlibur, berolahraga, berbisnis, maupun sekedar mengunjungi suatu tempat tertentu. Perjalanan yang dilakukan wisatawan merupakan kunjungan singkat atau sementara dan menginap di tempat tujuan sedikitnya 24 jam (Yoeti, 1982 dan Suryadana 2013), walaupun akomodasi yang digunakan bukan merupakan akomodasi komersial (Pitana dan Diarta, 2009).

Pitana (2009) dan Gayatri (2005) mengelompokkan wisatawan ke dalam 3 kategori yaitu:

1. Traveller, seseorang yang melakukan perjalanan dengan minimal dua daerah yang berbeda.

2. Visitor, seseorang yang melakukan perjalanan sementara ke daerah yang bukan merupakan tempat tinggalnya dengan tujuan berlibur dan durasi kurang dari 12 bulan.

3. Tourist, yaitu bagian dari visitor yang menghabiskan waktu paling tidak satu malam (24 jam) di daerah yang dikunjungi (WTO, 1995 dalam Pitana, 2005).

Yoeti (1982) juga memasukkan pelancong sebagai salah satu jenis wisatawan. Pelancong merupakan pengunjung sementara yang tinggal kurang dari 24 jam di daerah yang dikunjunginya.

\section{Perilaku wisatawan}

Perilaku wisatawan merupakan gabungan dari proses dan kegiatan mencari, memilih, menggunakan, mengevaluasi terhadap barang atau jasa sesuai dengan keinginan dan kebutuhannya (Morrisan dalam Suryadana, 2013). Suryadana (2013) menjabarkan tahapan di dalam proses pembentukan perilaku sebagai berikut:

1. Tahap perolehan, mencari, dan membeli,

2. Tahap konsumsi dan evaluasi,

3. Tahap tindakan setelah pembelian(konsumsi).

\section{Tata Ruang}

Ruang merupakan sistem lingkungan binaan terkecil yang berperan penting karena sebagian besar waktu manusia dihabiskan di dalamnya (Haryadi dan Setiawan, 2014). Ruang merupakan wadah bagi aktivitas manusia, sehingga mempengaruhi pola perilaku penggunanya (Laurens, 2005). Pola dan perilaku manusia dapat dibedakan menjadi dua bagian, yaitu proses individual dan proses sosial. Kedua proses tersebut tidak terlepas dari pengaruh dampak lingkungannya (Laurens, 2005).

Ruang yang merupakan bagian dari lingkungan memiliki beberapa komponen penting yang dapat mempengaruhi pola perilaku manusia, diantaranya 1) warna ruang, 2) ukuran dan bentuk, 3) perabot dan penataanya, dan 4) suara, temperatur, dan pencahayaan (Haryadi dan Setiawan, 2014).

Salah satu jenis pendekatan yang dapat digunakan untuk mengetahui pengaruh ruang terhadap pengguna adalah pendekatan sensori atau stimulu dengan memperhatikan rangsangan dari luar individu sebagai pengguna ruang. Rangsangan tersebut terhubung dengan reseptor, yakni indera manusia yang memiliki kemampuan menerima informasi dari luar. Apabila rangsangan yang diterima kuat, maka reseptor akan meneruskan pada selselnya sehingga terjadi penginderaan (Laurens, 2005).

\section{METODOLOGI PENELITIAN}

Metode penelitian yang digunakan pada penelitian ini adalah deskriptif-observatif dengan menerapkan teknik pengumpulan data observasi dan wawancara. Observasi digunakan untuk melakukan pemetaan ruang dan melihat kecenderungan perilaku wisatawan di area penelitian yang difokuskan pada sore sampai malam hari dengan memperhatikan jumlah pengunjung yang tinggi dan intensitas kegiatan yang aktif pada waktu tersebut, sedangkan wawancara mendalam digunakan untuk mengetahui latar belakang perilaku yang dilakukan wisatawan di area penelitian.

Variabel yang akan digunakan dalam penelitian ini adalah komponen dasar keruangan yaitu 1) ukuran dan bentuk, 2) perabot dan penataanya, dan 3) pencahayaan. Hasil pengamatan terkait pola perilaku dan tata ruang akan disajikan dengan visualisasi gambar. Pemetaan dan pengamatan difokuskan pada sore sampai malam hari.

\section{HASIL PENELITIAN DAN PEMBAHASAN}

Titik Nol Kilometer Yogyakarta sebagai destinasi wisata memiliki beberapa atraksi yang merupakan daya tarik wisata dan fasilitas penunjang yang diperuntukkan bagi wisatawan (Gambar 1). Atraksi 
atau daya tarik wisata terdiri dari atraksi permanen berupa bangunan bersejarah dan atraksi temporer berupa pertunjukan seni dan pameran seni patung.

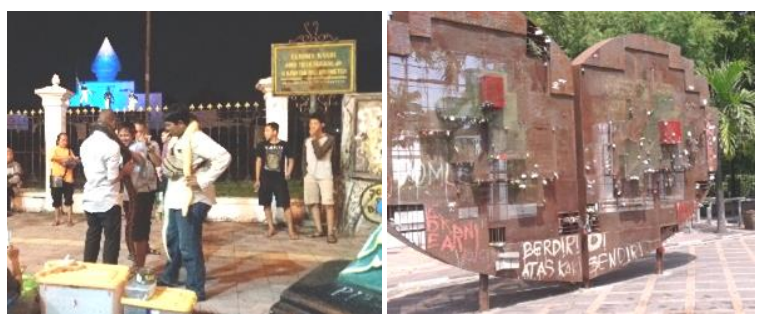

Gambar 1. Atraksi non permanen Titik Nol (sumber: dokumentasi penulis, 2019)

Fasilitas yang tersedia di kawasan ini adalah kursi taman, kursi pohon, lampu taman yang juga dimanfaatkan sebagai fasilitas untuk memajang jenisjenis batik, tempat sampah, dan papan penunjuk arah. Berdasarkan hasil pengamatan, fasilitas yang paling sering digunakan wisatawan adalah kursi taman, sedangkan kursi pohon cenderung jarang digunakan karena terletak di titik yang kurang pencahayaan.

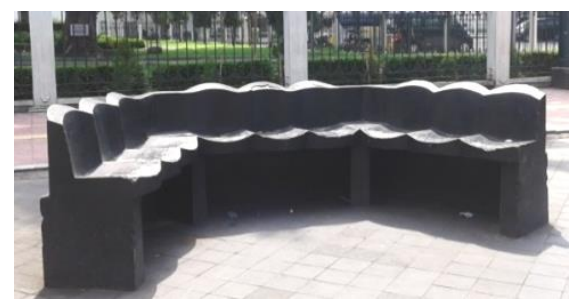

Gambar 2. Kursi taman di area penelitian (sumber: dokumentasi penulis, 2019)

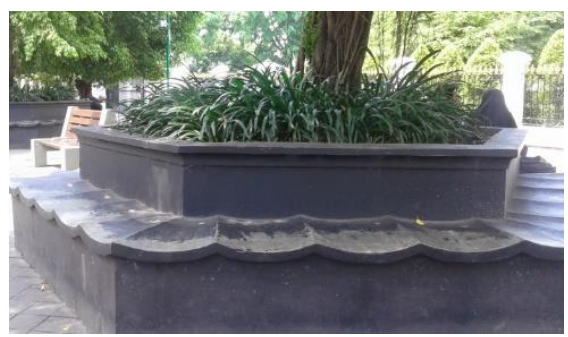

Gambar 3. Kursi pohon di area penelitian (sumber: dokumentasi penulis, 2019)

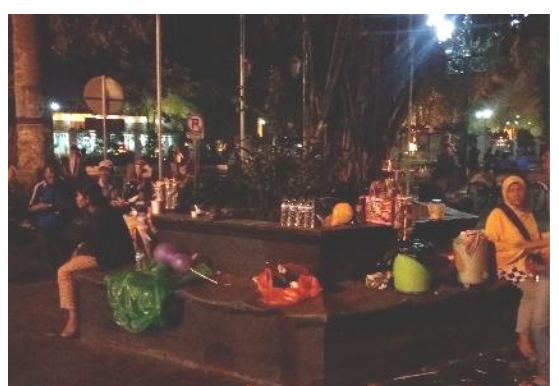

Gambar 4. Pemanfaatan kursi pohon oleh pedagang (sumber: dokumentasi penulis, 2019)
Kurangnya pencahayaan mengakibatkan timbulnya rasa kurang nyaman bagi wisatawan untuk berada di area kursi pohon. Selain itu, kursi pohon seringkali digunakan pedagang dan tukang becak untuk beristirahat dengana cara duduk maupun berbaring. Gambar 5 menunjukkan pemetaan titik atraksi dan fasilitas di area penelitian.

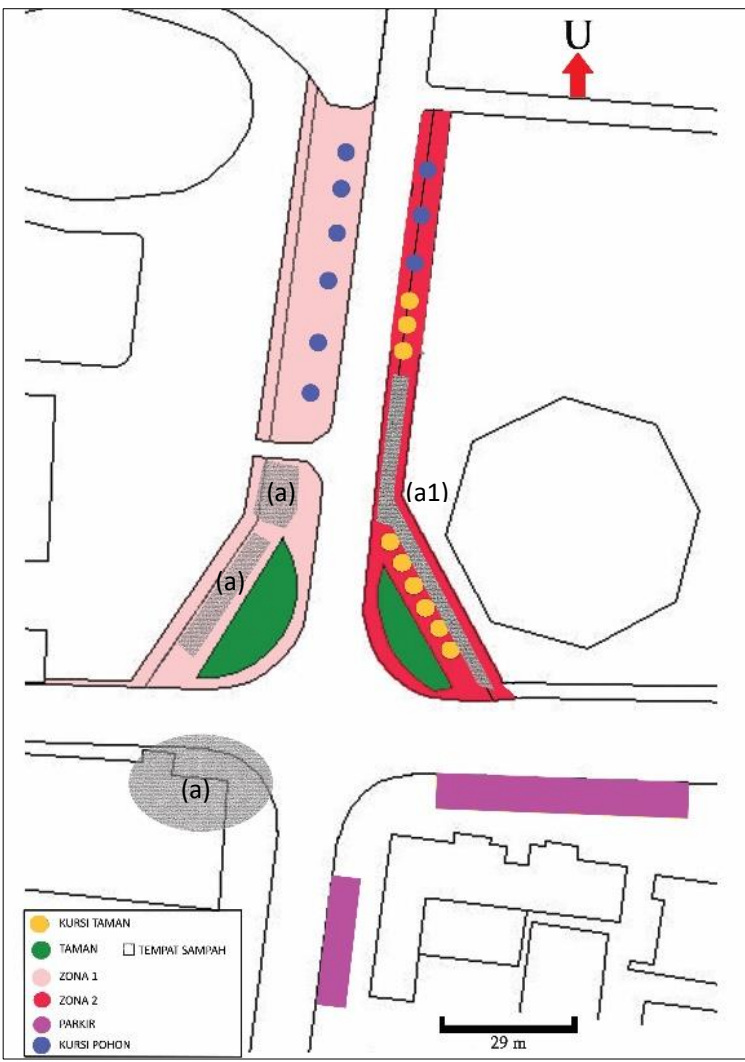

Gambar 5. Persebaran Atraksi dan Fasilitas (sumber: dokumentasi penulis, 2019)

Berdasarkan Gambar 5, atraksi wisata (blok abu-abu(a) dan (a1)) di zona 1 (pink) dan zona 2 (merah) memiliki persebaran yang merata. Perbedaan atraksi pada zona 1 dan 2 terdapat pada jenisnya. Zona 1 memiliki atraksi permanen berupa lampu taman yang difungsikan untuk pameran batik dan bangunan kesenian temporer. Sedangkan atraksi di zona 2 didominasi atraksi temporer berupa patung seni dan pertunjukan badut, robot, maupun hantu-hantuan.

Variabel pertama terkait ukuran dan bentuk ruang menunjukkan ukuran dan bentuk keruangan zona 1 dan 2 cenderung memiliki kesamaan. Variabel kedua terkait penataan fasilitas atau perabot, zona 1 memiliki penataan yang lebih padat dibandingkan zona 2. Pelataran Titik Nol pada zona 1 memiliki karakteristik yang berbeda dengan zona 2 . Zona 1 memiliki karakteristik ruang yang cenderung tertutup, sedangkan zona 2 memiliki karakteristik ruang yang lebih terbuka. Sementara itu perabot di zona 1 cenderung lebih padat dibandingkan dengan zona 2 dikarenakan keberadaan lampu yang difungsikan 
untuk pameran batik. Bentuk ruang yang lebih tertutup juga mengakibatkan zona 1 menjadi tempat buang air kecil bagi beberapa pedagang kaki lima dan tukang becak di sekitar tempat ini. Keadaan tersebut menjadikan zona 1 memiliki aroma yang kurang sedap yang dapat dirasakan saat melintasi zona ini. Variabel ketiga terkait pencahayaan didapati di zona 1 memiliki pencahayaan lebih redup, sehingga menjadikannya tidak banyak disinggahi oleh wisatawan. Redupnya pencahayaan dan karateristik ruang yang lebih tertutup pada zona 1 menyebabkan rasa tidak nyaman bagi wisatawan untuk dudukduduk atau singgah di zona ini.

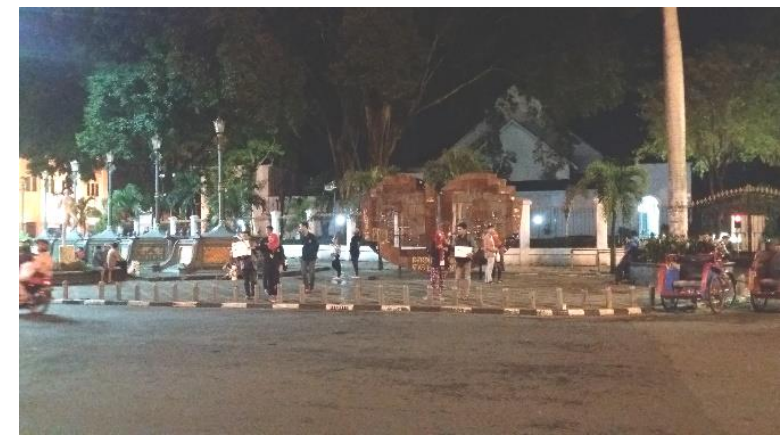

Gambar 6. Sudut pandang zona 1 dari dari zona 2 (sumber: dokumentasi penulis, 2019)

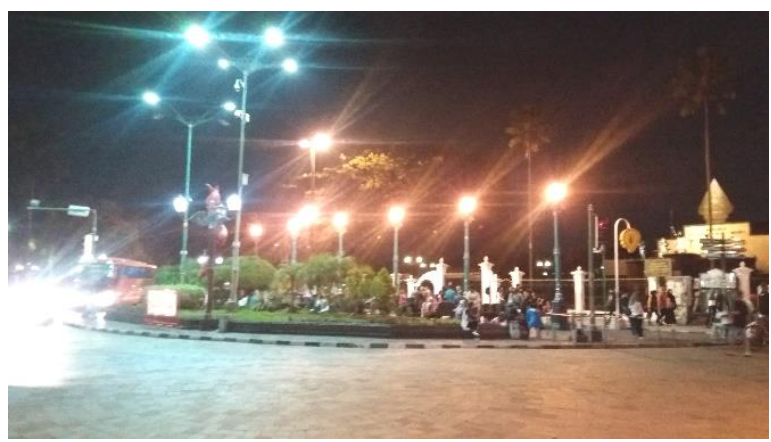

Gambar 7. Sudut pandang zona 2 dari dari zona 1 (sumber: dokumentasi penulis, 2019)

Gambar 8 merupakan penggabungan data pengamatan titik atraksi dan fasilitas dengan titik kepadatan atau keramaian wisatawan di zona 1 dan 2. Titik kepadatan wisatawan digambarkan dengan warna biru. Ketebalan warna biru mengartikan titik paling padat/ramai wisatawan. Sebagaimana ditunjukkan gambar tersebut, zona 2 memiliki tingkat kepadatan lebih tinggi dibandingkan zona 1. Karakteristik zona 2 yang lebih terbuka cenderung lebih diminati wisatawan dibandingkan pemadatan atraksi wisata di zona 1 yang membuat karakteristik ruang lebih padat. Selain itu lampu-lampu yang juga berfungsi sebagai atraksi pameran batik yang terdapat di zona 1 juga kurang diminati wisatawan.

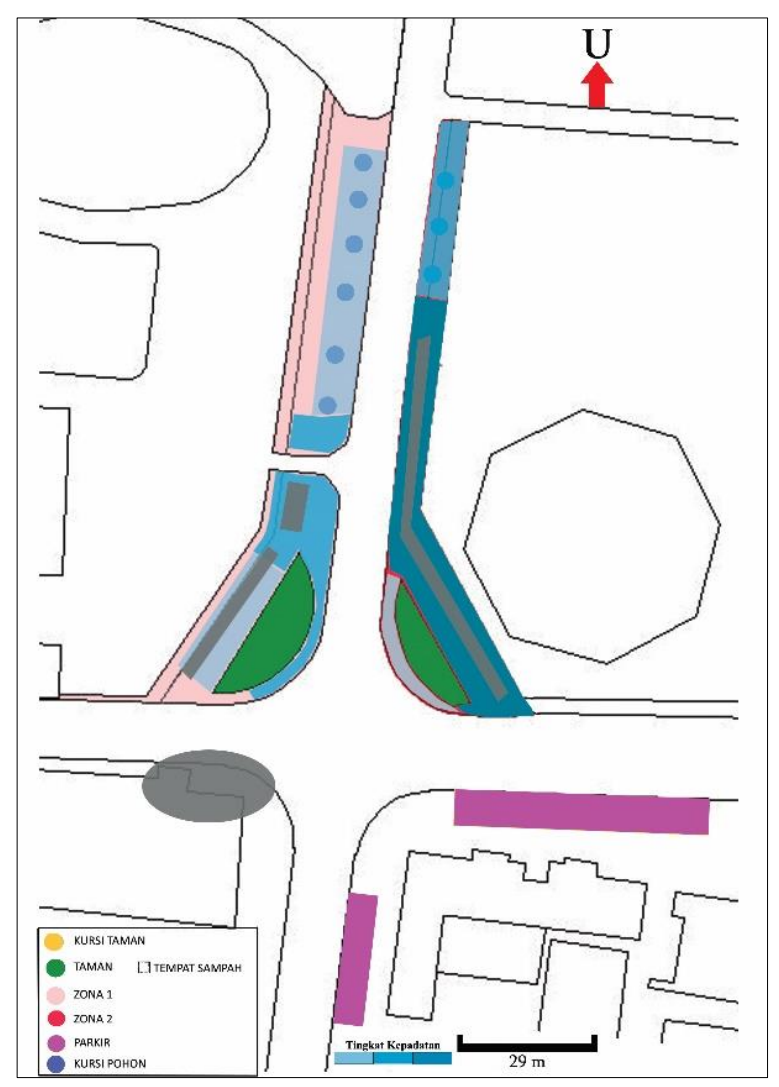

Gambar 8. Pemetaan titik keramaian wisatawan

(sumber: dokumentasi penulis, 2019)

\section{KESIMPULAN}

Titik keramaian wisatawan di Titik Nol Kilometer Yogyakarta terdapat di pelataran bagian Barat yang merupakan zona 1 penelitian dan Timur simpang empat nol kilometer yang merupakan zona 2 area penelitian. Karakteristik keruangan zona 1 dan zona 2 memiliki perbedaan pada penataan perabot, persebaran atraksi wisata, dan pencahayaan, sedangkan ukuran dan bentuk ruang cenderung serupa. Zona 1 memiliki karakteristik keruangan dengan perabot yang lebih padat, pencahayaan redup, dam atraksi wisata didominasi atraksi wisata permanen. Zona 2 memiliki karakteristik penataan perabot lebih sedikit, pencahayaan lebih terang, dan didominasi atraksi wisata temporer. Karakteristik keruangan zona 1 yang lebih padat dan gelap mengakibatkan perilaku wisatawan yang cenderung menjauhi zona ini dikarenakan wisatawan cenderung merasa lebih nyaman di zona 2 dengan konsep keruangan yang cenderung terbuka dan tidak terlalu dengan perabot permanan.

\section{DAFTAR PUSTAKA}

Haryadi dan Bakti Setiawan. (2014). Arsitektur, Lingkungan dan Perilaku: Pengantar ke Teori, 
Metodologi dan Aplikasi. Yogyakarta: Gadjah Mada University Press.

Laurens, J M. (2005). Arsitektur dan Perilaku Manusia. Jakarta: Grasindo.

Pitana, I. G dan Gayatri, P.G. (2005). Sosiologi Pariwisata. Yogyakarta: Penerbit Andi.

Pitana, I Gede dan Diarta, I Ketut Surya (2009). Pengantar Ilmu Pariwisata. Yogyakarta: Penerbit Andi.

Yoeti, Oka A. (1982). Pengantar Ilmu Pariwisata. Bandung:Penerbit Angkasa.

Suryadana, M Liga. (2013). Sosiologi Pariwisata: Kajian Kepariwisataan dalam Paradigma Integratif-Transformatif Menuju Wisata Spiritual. Bandung: Humaniora.

Swarbrooke, John, Susan Horner. (2004) Consumer behaviour in tourism, Oxford Elsevier Butterworth Heinemann, 